\title{
FACTORS ASSOCIATED WITH THE RISK OF ACUTE RESPIRATORY TRACT INFECTION AMONG CHILDREN UNDER FIVE IN ABDYA DISTRICT, ACEH
}

\author{
Fitriani
}

Faculty of Public Health, Universitas Teuku Umar.

\begin{abstract}
Background: Acute Respiratory Infection (ARI) is ranked in the 10 the highest disease incidence in Alue River, Jeumpa District, South-West Aceh. In 2015 there was 80 new cases (40.0\%). In 2016, the number of new cases increased to 138 cases $(87.1 \%)$. This study aimed to determine the factors associated with the risk of acute respiratory tract infection among children under five in Abdya District, Aceh.

Subjects and Method: This was a case control study carried out in Abdya district, Aceh. A total of 138 children under five was selected for this study using purposive sampling technique, consisting 2 groups: case and control groups. The dependent variable was ARI. The independent variables were low birth weight (LBW), nutritional status, exclusive breastfeeding, immunization status, ventilation, floor type, and smoke exposure. The data on ARI, LBW, and immunization status were collected from medical record. The other data were collected by questionnaire. The data were analyzed using logistic regression.

Results: Incidence of ARI increased with LBW ( $O R=13.43 ; \mathrm{p} \leq 0.001)$, low nutritional status $(\mathrm{OR}=12.25 ; \mathrm{p} \leq 0.001)$, non-exclusive breastfeeding $(\mathrm{OR}=7.31 ; \mathrm{p} \leq 0.001)$, no immunization $(\mathrm{OR}=9.09 ; \mathrm{p} \leq 0.001)$, absence of ventilation $(\mathrm{OR}=5.88 ; \mathrm{p} \leq 0.001)$, bad floor type $(O R=16.38 ; p \leq 0.001)$, and frequent smoke exposure $(O R=23.26 ; p \leq 0.001)$.

Conclusion: Incidence of ARI increases with LBW, low nutritional status, nonexclusive breastfeeding, no immunization, absence of ventilation, bad floor type, and frequent smoke exposure.
\end{abstract}

Keywords: acute respiratory tract infection, low birth weight, exclusive breastfeeding, nutritional status, immunization, ventilation, floor type, smoke

\section{Correspondence:}

Fitriani. Faculty of Public Health, Universitas Teuku Umar, West Aceh.

Email: fitriani@utu.ac.id. Mobile: 085260448181.

The $5^{\text {th }}$ International Conference on Public Health Best Western Premier Hotel, Solo, Indonesia, February 13-14, 2019 | 71 https://doi.org/10.26911/theicph.2019.01.17 